\title{
Growth, morphology and haematology of Double-spurred Francolin (Francolinus bicalcaratus): A prelude to its captive breeding and domestication \\ ${ }^{1}$ Aro, S. O., ${ }^{2}$ Adewumi, A. A. and ${ }^{3}$ Ogunjinmi, A. A. \\ ${ }^{\prime}$ Department of Animal Production and Health, \\ Federal University of Technology, Akure, Nigeria. \\ ${ }^{2}$ Department of Fisheries and Wildlife Management, College of Agriculture, \\ Osun State University, Osogbo, Nigeria. \\ ${ }^{3}$ Department of Ecotourism and Wildlife Management, \\ Federal University of Technology, Akure, Nigeria.
}

Abstract

Corresponding author: soaro@futa.edu.ng; +2347062329254

It has been documented that broadening the genetic diversity of the livestock population through captive breeding and eventual domestication of game animals could be one of the palliatives for reducing animal protein malnutrition in sub-Saharan Africa. One of the game birds with wide culinary appeal in West Africa that can easily be captive-bred is the Doublespurred Francolin (Francolinus bicalcaratus). This study was therefore conducted to determine the growth, morphology and haematological indices of Double spurred Francolin reared under intensive management condition. Eighteen eggs of Double spurred Francolin collected from the wild were artificially incubated and hatched into chicks. These chicks were subsequently reared intensively for 24 weeks while taking data on their feed intake, growth, plumage development, vocalization and haematological indices. The growth curve of F. bicalcaratus was modelled from which the peri-pubertal period of this bird was determined. Also the number of rectrices and remiges from day old to the $24^{\text {th }}$ week of age were determined while the first adult vocalization was observed in the fifth month. Francolinus bicalcaratus displays sexual dimorphism in terms of body size, vocalization and tarsal spur number and development. Double spurred Francolin has growth and morphometric parameters that are similar to its other phasianid relatives and can therefore fit into the food security equation geared towards solving the perennial animal protein malnutrition problem especially in the West African sub-region. It is concluded that the bird is a good candidate for domestication and conservation, a two in -one effort that could re-write its current global signature as an endangered bird species of West Africa.

Keywords: Double-spurred francolin, growth, haematology, plumage, vocalization.

\section{Introduction}

The Double-spurred Francolin is a game bird that belongs to the Order-Galliformes and to the Family-Phasianidae or the Pheasant family. Birds of this family are generally referred to as the game bird of the world and include the ring-necked pheasant (Phasianus cholchicus), the Bobwhite quail (Colinus virginianus), the Chukar partridge (Alectoris gracea chukar), grey partridge (Perdix perdix), Tibetan snowcock (Tetraogallus tibetanus), wild turkey (Meleagris gallopavo), the Japanese quail
(Coturnix coturnix japonica) and the Double-spurred Francolin (Francolinus bicalcaratus). According to International Union of the Conservation of Nature (IUCN, 2009), the survival of many of these birds is currently being threatened, endangered or at the brink of extinction. These game birds play a significant role in the meat supply of the various countries where they are resident breeders (Aro and Akinmoladun, 2016). The Double-spurred Francolin for instance is an acclaimed resident breeder of West African sub-region 


\section{Growth, morphology and haematology of Double-spurred Francolin (Francolinus bicalcaratus)}

and is conspicuous in the menu of the people of this region without any religious, social or cultural constraints against the use of its meat for food (Ntiamoa-Baidu, 1997; Aro and Akinmoladun, 2015). Doublespurred Francolin, otherwise called African bush fowl has however suffered gradual decimation from many fronts due partly to increased hunting pressure, its status as a potential crop pest and hence an increased drive towards its annihilation and the rapid urbanization in the sub-region which has now reduced the natural habitats of this game bird, thus exposing it to conditions inimical to its breeding under natural settings (Aro et al., 2014; Aro and Akinmoladun, 2015). To save this game bird from possible future extinction, research efforts towards its domestication, multiplication and commercialization should be sought. Such research efforts include but are not limited to the determination of growth, morphology and haematological indices of this game bird. Kokoszyński et al. (2013) reported on the carcass composition and meat quality of grey partridge $(P$. perdix) and concluded that both the male and female grey partridge had similar adult weight (301 .4 g versus $299.5 \mathrm{~g}$ ) at slaughter age of 32 weeks. The body weight of both male and female ringnecked pheasant from the $2^{\text {nd }}$ to $18^{\text {th }}$ week of age ranged from $85-1530 \mathrm{~g}$ and $85-1080 \mathrm{~g}$ respectively (Alabama Cooperative Extension System, 2009). Information on the growth pattern of Bobwhite quail $(C$. virginianus) from the same source showed that the body weight changed from an initial $16 \mathrm{~g}$ in the first week to $190 \mathrm{~g}$ in the $10^{\text {th }}$ week of age with a feed conversion ratio of 3.95. The growth curves of other domestic birds like the broilers, Japanese quails and female turkey (Anthony et al., 1991), kids (Najira et al., 2007) and Chukar partridge (Cetin et al., 2007) using different models have also been reported.
The blood parameters of game birds have not been left out of the research searchlight of investigators. For instance, Straková et al. (2010) analyzed blood samples from six species of game birds: helmeted guinea fowl (Numida meleagris), common pheasant ( $P$. colchicus), Japanese quail ( $C$. coturnix japonica), Chukar partridge $(A$. chukar), grey partridge (P. perdix) and wild turkey (M. gallopavo) and concluded that most of the values they obtained showed significant to highly significant interspecies differences. Similarly, Schmidt et al. (2007) reported on the blood values of ring-necked pheasant ( $P$. colchicus) and drew a conclusion that statistically significant differences existed between the age and sex of this species of bird. Studies on growth, plumage development and blood parameters of Double-spurred Francolin managed under intensive condition have not been reported in the literature. This paper thus reports on an experiment conducted on the growth, plumage development and haematological profile of Double spurred Francolins raised under intensive management conditions from day old to six months of age.

\section{Materials and methods}

Eighteen eggs of Double-spurred Francolin from three clutches, made up of seven eggs apiece from the first two clutches and four eggs from the third clutch were collected from fallow lands within the precincts of the Federal University of Akure, Nigeria. Akure is located on latitude $7^{\circ} 52^{\prime} \mathrm{N}$ and longitude $5^{\circ} 12^{\prime} \mathrm{E}$ of Greenwich meridian and has a bimodal rainfall pattern characteristic of the hot, wet equatorial climate. The eggs were artificially incubated and hatched into chicks. These chicks were subsequently brooded for three weeks in an improvised brooder box and were thereafter reared intensively within a rectangular enclosure covered with 


\section{Aro, Adewumi and Ogunjinmi}

mosquito net to prevent the birds from escaping. The floor of the enclosure was covered with wood shavings which served as the litter materials. The light regimen varied between $12-13$ hours of daylight throughout the 24 weeks of the experiment. The enclosure measured $2 \mathrm{~m} \times 3 \mathrm{~m}$ and was $1 \mathrm{~m}$ high. The birds were fed ad libitum with feed and water daily. The energy density of the feed was $3011.08 \mathrm{kcalME} / \mathrm{kg}$ with a crude protein of $41.71 \%$ (Table 1). This feed was fed throughout the duration of the experiment. They were weighed weekly to determine the weekly weight change and since no overnight feeding was done, the birds were weighed between 6.00 hours and 7.00 hours before the commencement of feeding. The quantity of feed consumed was also recorded. Periodic determination of plumage development especially of the tail feathers (rectrices) and primary and secondary wing feathers (remiges) was taken every month.

Table 1: Gross composition $(\mathrm{kg} / 100 \mathrm{~kg})$ of the experimental diet

\begin{tabular}{ll}
\hline Feed Ingredients & Composition \\
\hline Maize & 16.17 \\
Fish meal & 33.33 \\
Full fat soybean meal & 50.00 \\
*Premix & 0.50 \\
Total & 100 \\
\hline
\end{tabular}

$*$ Each $\mathrm{kg}$ of premix contains Antioxidant (125,000 mg), Folic Acid (500 mg), Niacin (15,000 mg), Calpan (5000 mg), Biotin (20 mg), Vitamin A (10,000,000 I.U), B1 (1,500 mg), B2 (500 mg), B6 (1,500 mg), B12 (10 mg), D3 (2,200,000 I.U), E (10,000 mg), and K3 (2,000 mg), Selenium (200 mg), Iodine (1,000 mg), Iron (40,000 mg), Cobalt (200 mg), Manganese (70,000 mg), Copper (4,000 mg), Zinc (50,000 mg) and Choline Chloride (150,000 $\mathrm{mg}$ ).

The primary feathers are connected to the manus which is made up of the carpometacarpus and phalanges while the secondary feathers are attached to the ulna. The periods of initiation of the development of the spurs and adult vocalization were also documented. Blood samples (3 $\mathrm{ml}$ each) were taken from the birds via the left brachial vein in the last week of the experiment to determine their haematological profile. All analyses on haematology were carried out according to the procedures of Jain (1986). All data obtained were subjected to statistical analysis where means were computed and compared using one sample t-test with SPSS (2006) statistical package.

\section{Results}

Table 2 shows the weekly body eight change of the birds from day old to the $24^{\text {th }}$ week of age.

The body weight increased from the initial weight of $15.50 \mathrm{~g}$ in the first week of life to $318.25 \mathrm{~g}$ in the last week of the experiment. The birds thus had an average body weight gain of $302.75 \mathrm{~g}$ during the entire period of the experiment. A period of rapid growth was observed between week 11 with a weight change of $18.25 \pm 3.30 \mathrm{~g}$ and week 16 with a weight change of $29.25 \pm 0.63 \mathrm{~g}$.

Table 3 summarized the weekly data into monthly data to give better appraisal of the body weight change of the birds on monthly basis. From the Table, the highest body weight gain $(21.99 \mathrm{~g})$ was recorded in the fourth month of the study. This period coincided with the $11^{\text {th }}$ to the $16^{\text {th }}$ week of age of the birds as observed in Table 2 . 
Table 2: Weekly body weight change of Francolinus bicalcaratus from day old to 24 weeks of age

\begin{tabular}{llll}
\hline Week & Initial Weight & Final Weight & Weight Gain \\
\hline 1 & $15.50 \pm 0.29$ & $22.25 \pm 0.85$ & $6.75 \pm 0.63$ \\
2 & $22.25 \pm 0.85$ & $27.50 \pm 1.32$ & $5.25 \pm 0.63$ \\
3 & $27.50 \pm 1.32$ & $35.75 \pm 2.25$ & $8.25 \pm 0.95$ \\
4 & $35.75 \pm 2.25$ & $49.00 \pm 1.83$ & $13.25 \pm 0.85$ \\
5 & $61.75 \pm 1.44$ & $12.75 \pm 0.63$ \\
6 & $69.00 \pm 1.83$ & $67.00 \pm 1.87$ & $5.25 \pm 1.03$ \\
7 & $61.75 \pm 1.44$ & $82.25 \pm 2.36$ & $15.25 \pm 0.63$ \\
8 & $67.00 \pm 1.87$ & $96.00 \pm 3.81$ & $13.75 \pm 1.84$ \\
9 & $82.25 \pm 2.36$ & $109.00 \pm 4.95$ & $13.00 \pm 1.22$ \\
10 & $96.00 \pm 3.81$ & $122.25 \pm 5.57$ & $13.25 \pm 0.63$ \\
11 & $109.00 \pm 4.95$ & $140.50 \pm 8.33$ & $18.25 \pm 3.30$ \\
12 & $122.25 \pm 5.57$ & $165.50 \pm 11.72$ & $25.00 \pm 3.56$ \\
13 & $140.50 \pm 8.33$ & $182.50 \pm 14.24$ & $17.00 \pm 2.55$ \\
14 & $165.50 \pm 11.72$ & $209.50 \pm 19.28$ & $27.00 \pm 5.31$ \\
15 & $182.50 \pm 14.24$ & $224.25 \pm 16.09$ & $14.75 \pm 3.30$ \\
16 & $209.50 \pm 19.28$ & $253.75 \pm 16.44$ & $29.25 \pm 0.63$ \\
17 & $224.25 \pm 16.09$ & $268.75 \pm 17.11$ & $15.00 \pm 0.71$ \\
18 & $253.75 \pm 16.44$ & $287.75 \pm 18.08$ & $19.00 \pm 1.08$ \\
19 & $268.75 \pm 17.11$ & $280.75 \pm 20.11$ & $-7.00 \pm 3.34$ \\
20 & $287.75 \pm 18.08$ & $289.00 \pm 21.65$ & $8.25 \pm 1.55$ \\
21 & $280.75 \pm 20.11$ & $293.00 \pm 20.31$ & $4.00 \pm 1.47$ \\
22 & $289.00 \pm 21.65$ & $303.00 \pm 18.00$ & $10.00 \pm 3.24$ \\
23 & $293.00 \pm 20.31$ & $312.25 \pm 18.97$ & $9.25 \pm 1.49$ \\
24 & $303.00 \pm 18.00$ & $318.25 \pm 19.69$ & $6.00 \pm 0.82$ \\
\hline & $312.25 \pm 18.97$ & &
\end{tabular}

Table 3: Average monthly body weight and weight gain of double-spurred Francolin raised under intensive management condition for six months

\begin{tabular}{lll}
\hline Month & Average body weight $(\mathrm{g})$ & Average weight gain $(\mathrm{g})$ \\
\hline 1 & $25.25 \pm 1.18$ & $8.38 \pm 0.77$ \\
2 & $65.00 \pm 1.88$ & $11.75 \pm 1.03$ \\
3 & $116.94 \pm 5.67$ & $17.38 \pm 2.18$ \\
4 & $195.44 \pm 15.33$ & $21.99 \pm 2.95$ \\
5 & $272.75 \pm 17.94$ & $8.81 \pm 1.67$ \\
6 & $299.31 \pm 19.73$ & $7.31 \pm 1.76$ \\
Computed Statistics & \\
CWG/bird = 305.17g & \\
AFC/bird = 1.25kg & \\
FCR for the period = 4.10 & \\
CWG $=$ Cumulative average weight gain of each bird for the entire period; AFC $=$ Average feed consumption/bird; FCR $=$ Feed \\
conversion ratio
\end{tabular}
conversion ratio 
The haematological parameters of Doublespurred Francolin are as shown in Table 4. The erythrocyte sedimentation rate of the birds averaged $5.67 \pm 3.28 \mathrm{mmhr}^{-1}$ while the haematocrit, red blood cells and haemoglobin concentration of the blood were $40.33 \pm 4.98 \%, 3.38 \pm 0.28 \times 10^{6} \mathrm{~mm}^{3}$ and $13.43 \pm 1.67 \mathrm{gdL}^{-1}$, respectively. The values for mean corpuscular haemoglobin, mean corpuscular haemoglobin concentration and mean corpuscular volume were $39.59 \pm 1.85 \mathrm{pg}, 33.30 \pm 0.03 \%$ and $118.89 \pm 5.46 \mathrm{fl}$, respectively. The leucogram values for these birds revealed that the lymphocytes stood at $61.68 \pm 1.76 \%$, heterophils at $20.68 \pm 0.88 \%$ and monocytes at $13.34 \pm 0.88 \%$ while eosinophils and basophils were $3.34 \pm 0.33 \%$ and $1.00 \pm 0.00 \%$, respectively. Table 5 gives records of the monthly observation of the development of primary and secondary wing feathers, tail feathers and tarsal spurs in F. bicalcaratus.

Table 4: The haemogram and leucogram of Francolinus bicalcatatus at six months of age

\begin{tabular}{ll}
\hline Parameters & Mean Values \\
\hline Erythrocyte sedimentation rate $(\mathrm{mm} / \mathrm{Hr})$ & $5.67 \pm 3.28$ \\
Haematocrit $(\%)$ & $40.33 \pm 4.98$ \\
Red blood corpuscles $\left(\mathrm{x} 10^{6} \mathrm{~mm}^{-3}\right)$ & $3.38 \pm 0.28$ \\
Haemoglobin (g/dL) & $13.43 \pm 1.67$ \\
Mean corpuscular haemoglobin $(p g)$ & $39.59 \pm 1.85$ \\
Mean corpuscular haemoglobin concentration (\%) & $33.30 \pm 0.03$ \\
Mean corpuscular volume $(f l)$ & $118.89 \pm 5.46$ \\
Lymphocytes (\%) & $61.68 \pm 1.76$ \\
Heterophils (\%) & $20.68 \pm 0.88$ \\
Monocytes (\%) & $13.34 \pm 0.88$ \\
Eosinophils (\%) & $3.34 \pm 0.33$ \\
Basophils (\%) & $1.00 \pm 0.00$ \\
\hline
\end{tabular}

Table 5: Plumage and spur development in Francolinus bicalcaratus raised under intensive management condition

\begin{tabular}{|c|c|c|c|c|}
\hline Month & $\begin{array}{l}\text { Number of primary } \\
\text { feathers }\end{array}$ & $\begin{array}{l}\text { Number of } \\
\text { secondary feathers }\end{array}$ & $\begin{array}{l}\text { Number tail } \\
\text { feathers }\end{array}$ & $\begin{array}{l}\text { Tarsal spur } \\
\text { development }\end{array}$ \\
\hline 1 & 7 & 8 & 10 & None \\
\hline 2 & 9 & 8 & 10 & None \\
\hline 3 & 10 & 9 & 11 & $\begin{array}{l}\text { Budding of the lower } \\
\text { spur }\end{array}$ \\
\hline 4 & 10 & 11 & 11 & $\begin{array}{l}\text { Budding of the upper } \\
\text { spur }\end{array}$ \\
\hline 5 & 10 & 13 & 13 & $\begin{array}{l}\text { Protuberance of both } \\
\text { spurs }\end{array}$ \\
\hline 6 & 10 & 15 & 14 & $\begin{array}{l}\text { Elongation of both } \\
\text { spurs commenced }\end{array}$ \\
\hline
\end{tabular}

The number of primary wing feathers, secondary wing feathers and tail feathers for the first month of life in F. bicalcaratus were 7,8 and 10, respectively. In the second month, the number of primary wing feathers increased from 7 to 9 while the other two parameters remained constant. Spur development was not observed during the first two months of life in F. bicalcaratus. The third month of life witnessed the first sign of budding of the lower tarsal spur and an increase in the number of primary 
feathers to 10 , secondary feathers to 9 and tail feathers to 11 . At the fourth month of age, the budding of the upper spur became visible while that of the lower spur became more prominent as a protuberance on the inner surfaces of the tarsi. It was observed that spur development in this species of bird is sexually dimorphic as only the male birds show this evidence of tarsal spur development, also the difference in morphological features as regards a more robust body of the male became apparent at this age (Plate 1$)$.

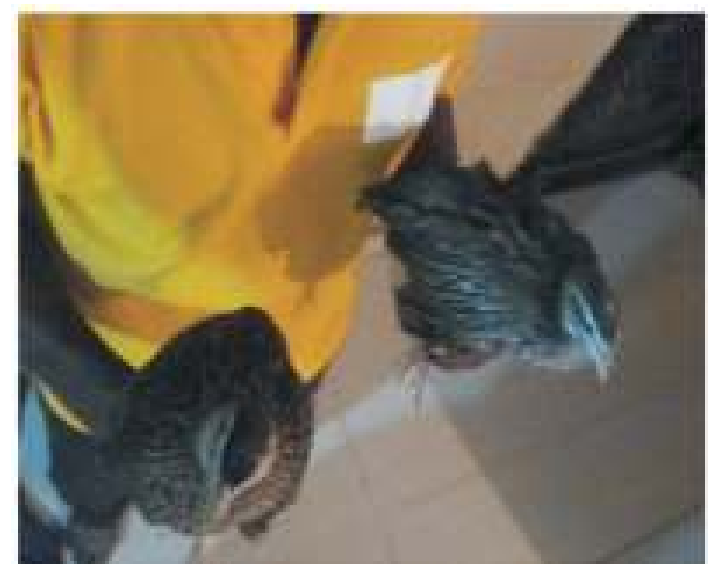

Plate 1: Sexual dimorphism showing a more robust and heavier male (left) at 6 months of age than the female (right)

The evidence of spur development could therefore be used for sex differentiation in Double-spurred Francolin. The number of primary wing and tail feathers remained constant at 10 and 11 , respectively while the secondary feathers increase from 9 to 11. Rapid shedding and simultaneous renewal of feathers was also observed during this period especially of the wing, tail and contour feathers. In the fifth month, the primary feathers remained constant at10 while the secondary and tail feathers increased to 13 apiece, also both the tarsal spurs showed prominent protuberances on the tarsi. The tarsal spurs began to elongate and became measurable $(4 \mathrm{~mm})$ in the sixth month, also the birds vocalised for the first time at dawn and dusk. The primary wing feathers remained at 10 while the secondary feathers increased to 15 and the tail feathers to 14 in the sixth month of age.

\section{Discussion}

Table 2 revealed that the growth pattern shown by these birds is similar to that of Bobwhite quail that started off with an initial weight of $16 \mathrm{~g}$ in the first week of life and attained $190 \mathrm{~g}$ at 10 weeks of age (Alabama Cooperative Extension System, 2009). The growth curve of the birds (Figure 1) is however better described by the growth curve models of male and female Chukar partridge (A. chukar) as reported by Cetin et al. (2007). This is because both the Chukar partridge and Double-spurred francolin are bigger birds than both the Bobwhite and Japanese quails and hence have a longer growth period for the attainment of sexual maturity. For instance, sexual maturity in Bobwhite quail occurs around 10 weeks of age while that of Japanese quail is between 7-8 weeks of age when the body weight would be between 150-160g. Kokoszyński et al. (2013) put 


\section{Aro, Adewumi and Ogunjinmi}

the mature age of the grey partridge at 12 weeks. The Chukar partridge on the other hand will attain sexual maturity at about 1618 weeks of age. In fact, Cetin et al. (2007) calculated the period of attainment of 70 and $90 \%$ sexual maturity for Chukar partridge at between $10-12$ and $16-18$ weeks of age, respectively. Comparing the growth curve obtained for Double-spurred Francolin in this study (Figure 1) with that obtained by Cetin et al. (2007), it would be observed that the gradient of the slope became steeper between week 10 and week 18 of age and thereafter climbed less steeply up to the $24^{\text {th }}$ week of age for Double-spurred Francolin.

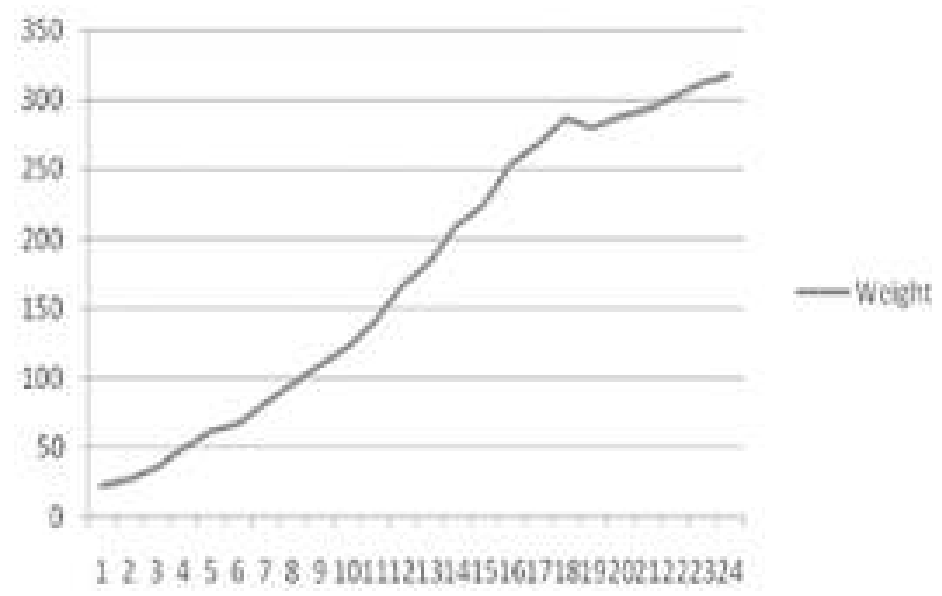

Figure 1: The growth curve of Francolinus bicalcaratus from $1^{\text {st }}$ to $24^{\text {th }}$ week of age

Animals are known to show a growth spurt that normally coincides with their peripubertal period-a period that sets off rapid growth registered by increased body weight change (Aro et al., 2011). Judging therefore from the point of inflection of the growth curve in Figure 1, it could be implied that the period of sexual maturity of African bush fowl is also between the $10^{\text {th }}$ and $18^{\text {th }}$ week of age just like its European Chukar partridge counterpart. Also with cumulative average weight gain of $305.17 \mathrm{~g} / \mathrm{bird}$, average feed consumption/bird of $1.25 \mathrm{~kg}$ and calculated feed conversion ratio (FCR) of 4.10 (Table 3), African bush fowl has similar growth parameters as observed in Chukar partridge (FCR of 5.10 at 12 weeks), grey partridge (FCR of 5.48 at 13 weeks) and ring-necked pheasant (FCR of 5.40 at 18 weeks) (Alabama Cooperative Extension System, 2009). The erythrocyte sedimentation rate obtained in this present study on Doublespurred Francolin (Table 4) fell within the normal range of values $(3-12 \mathrm{~mm} / \mathrm{hr}$ ) reported for domestic chickens by Jain (1993). Schmidt et al. (2007) gave the values of haematocrit or packed cell volume of adult male and female ringnecked pheasant as $43.5 \%$ and $38.7 \%$ respectively while Keçeci and Çöl (2011) gave $35.7 \%$ for the combined values of the male and female adults of the same species of bird. The haematocrit value $(40.33 \%)$ obtained in this present study was a bit higher than that reported by Keçeci and Çöl (2011) but at the same time lower than that reported by Schmidt et al. (2007) for the ring-necked pheasant. The difference in value could not be unconnected with species differences. The red blood cell (RBC) count of Double-spurred Francolin in this study was $3.38 \times 10^{6} \mathrm{~mm}^{-3}$. This value 
was higher than those reported by Straková et al. (2010) in helmeted guinea fowl ( $N$. meleagris $\left.\left[2.15 \times 10^{6} \mathrm{~mm}^{-3}\right]\right)$, common pheasant $\left(P\right.$. colchicus $\left.\left[2.58 \times 10^{6} \mathrm{~mm}^{-3}\right]\right)$, Japanese quail (C. coturnix japonica $[2.39 \times$ $\left.\left.10^{6} \mathrm{~mm}^{-3}\right]\right)$, Chukar partridge $(A$. chukar $\left.\left[2.57 \times 10^{6} \mathrm{~mm}^{-3}\right]\right)$, grey partridge $(P$. perdix $\left.\left[2.23 \times 10^{6} \mathrm{~mm}^{-3}\right]\right)$ and wild turkey $(M$. gallopavo $\left.\left[2.10 \times 10^{6} \mathrm{~mm}^{-3}\right]\right)$ but was lower than the results $\left(3.58 \times 10^{6} \mathrm{~mm}^{-3}\right)$ reported by Hauptmanová et al. (2006) in pheasants. The haemoglobin concentration (13.43 $\mathrm{g} / \mathrm{dL}$ ) obtained under this study compared with values of $12.91 \mathrm{~g} / \mathrm{dL}$ and $12.53 \mathrm{~g} / \mathrm{dL}$ reported by Straková et al. (2010) in helmeted guinea fowl ( $N$. meleagris) and Japanese quail ( $C$. coturnix japonica), respectively. The value was however lower than 15.96 and $16.74 \mathrm{~g} / \mathrm{dL}$ reported for both the male and female adult ring-necked pheasant by Schmidt et al. (2007). The values obtained for mean corpuscular haemoglobin $(\mathrm{MCH})$ [39.59pg], mean corpuscular haemoglobin concentration (MCHC) [33.30\%] and mean corpuscular volume $(\mathrm{MCV})$ [118.89 fl] of $F$. bicalcaratus (Table 4) fell within the range of values of these parameters for the domestic chicken reported by Jain (1993). The MCH compared with values for adult pheasants $(36.90 \mathrm{pg})$ but the MCV was lower than $139 \mathrm{fl}$ reported by Keçeci and Çöl (2011). The leucogram values (lymphocytes [61.68\%]; heterophils [20.68\%]; monocytes [13.34\%]; eosinophils [3.34\%]; basophils [1.00\%]) compared with values $(73.3 \% ; 21.1 \%$; $2.5 \% ; 2.4 \% ; 0.73 \%$, respectively) reported on the same parameters by Keçeci and Çöl (2011) in their works on differential leucocyte counts of adult ring-necked pheasant. These values were also in agreement with the range of values (45.070.0 [1ymphocytes]; $15.0-40.0$ [heterophils]; 5.0-10.0 [monocytes]; 1.5-
6.0 [eosinophils]; rare [basophils]) reported on the domestic chicken by Jain (1993). The monthly observation of the development of primary and secondary wing feathers, tail feathers and tarsal spurs in F. bicalcaratus is as shown in Table 5. It could be observed in this Table that $F$. bicalcaratus in the present study had 14 tail feathers at six months of age. The number of tail feathers is species specific and are often arranged in pairs. For instance, humming birds have five pairs (10 tail feathers), the ring-necked pheasants have nine pairs while the American white pelican has twelve pairs (Clark and Clark, 2015). The Double-spurred Francolin belongs to the same Order (Galliformes) and the same family (Phasianidae) as the ring-necked pheasant with nine pairs of tail feathers. The disparity in the number of their rectrices could be as a result of age. The determination of the number of rectrices of Double-spurred francolins used in this study was done monthly and the highest number of 14 (seven pairs) was observed in the sixth month. However, Johnsgard $(1988,1999)$ reported that a large number of rectrices $\geq 14$ can be used to identify the guinea fowls, the pavonines, the grey partridge, the turkey, grouse and pheasant. The first adult vocalisation was observed in these birds during the fifth month of life and is synonymous to 3-4 successive monosyllabic vocalisations in a single call described as "Kowaak-Kowaak-Kowaak raucous sound" by Van Niekerk (2013), the duration of which is usually between 4-5 seconds. These sounds are given by the males as a means of advertising their presence to rival males, prospective females and as a form of species to species recognition (Van Niekerk et al., 2009, Van Niekerk, 2012). The description of Mandiwane-Neudani (2014) that some more partridge-like francolins are relatively large and have two well-developed spurs on 


\section{Aro, Adewumi and Ogunjinmi}

both tarsi neatly fits the observation made on the spurs of Double-spurred francolins reported in the present study. Only the male F.bicalcaratus are double-spurred while the females are spurless (Plates 2 and 3). The presence of spurs in some species of the Order Galliformes has been hinged on mate choice by the females. Goransson et al. (1990) reported that harem females of ringnecked pheasant preferred males with longer spurs. Apart from using the size of

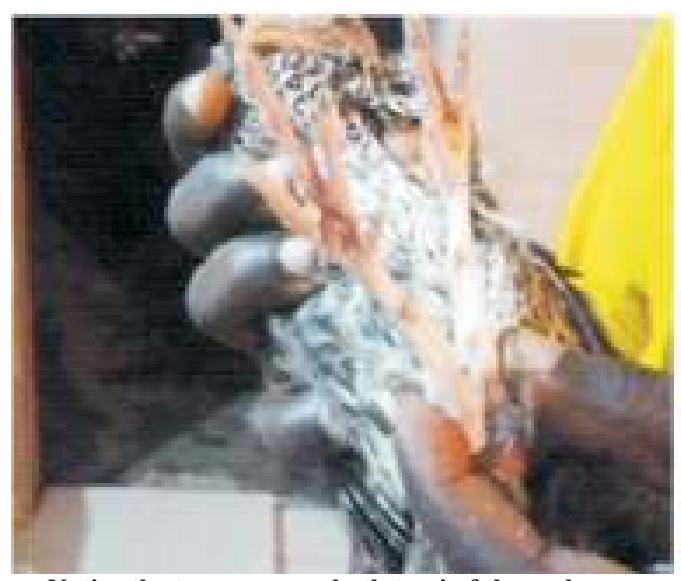

Notice the two spurs on both tarsi of the male

Plate 2: Spur development at 6 months of age

This explains the reasons for the loss of spurs in grouse and grey partridge. Crowe $e t$ al. (2006) noted that the presence of spurs could be a site of heat loss and may put the birds at a serious disadvantage during the harsh winter months of northern Eurasia.

\section{Conclusion}

The growth pattern, growth curve and age of attainment of sexual maturity in the Double-spurred Francolin (F. bicalcaratus) is similar to that of the Chukar partridge ( $A$. chukar), hence management practices in terms of feeding, handling and rearing of Chukar partridge could be extended to Francolinus bicalcaratus. Also, the spurs for mate preferences by the females, its presence or absence has been linked with whether the bird in question is a tropical or temperate resident breeder. This is because the evolution of spur development in Galliformes has its root in the use of the spur for heat dissipation; hence most Galliformes that evolved within the tropics have spurs for heat dissipation while those that evolved in the temperate regions are usually spurless.

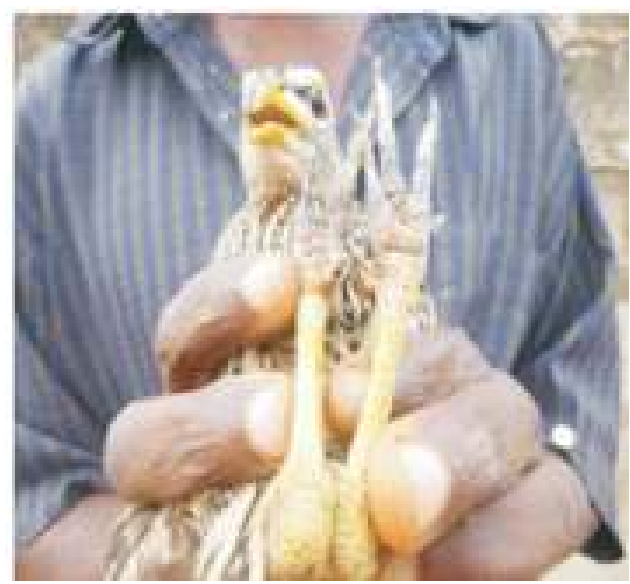

Notice the two spurs on both tarsi of the male Plate 3: Absence of spurs on the tarsi of the female

haematological parameters of Doublespurred Francolin observed in the present study compared with those of other Galliformes, a credence to the common ancestry shared by these birds. This study further confirmed the sexual dimorphism that exists among different clades under the Order Galliformes in terms of the presence or absence of tarsal spurs and types of adult calls and vocalization.

\section{Acknowledgement}

The authors wish to thank the management of the Federal University of Technology, Akure, Nigeria for the release of TETFund $\mathrm{R}$ e s e a r c h Grant fund s 
(VCPU/TETFund/155) with which this research project was carried out.

\section{References}

Alabama Cooperative Extension System, 2009. Feeding Game Birds: Pheasant, Quail, and Partridge. Alabama Cooperative Extension System. 5M, New March 2009, ANR-1343. Available at http://www.aces.edu/pubs/docs/A/ ANR-1343/ANR-1343.pdf

Anthony, N. B., Emmerson, D. A., Nestor, K. E., Bacon, W. L., Siegel, P. B. and Dunnington, E. A. 1991. Comparison of growth curves of weight selected population of turkeys, quails and chickens. Poultry Science, 70: 13-19

Aro, S. O. and Akinmoladun, F. O. 2015. Preliminary investigations on the domestication and adaptive breeding of African Bush Fowl (Francolinus bicalcaratus) Livestock Research for Rural Development,27: 80

Aro, S. O. and Akinmoladun, F. O. 2016. Double-spurred Francolin: Extolling the nutritional and reproductive potentials of a prized but lesser known game bird. In:A. A. Odunsi., S. G. Ademola., T. A. Rafiu., O. O. Ojebiyi., A. O. Akinwunmi (eds). 1st International Conference on Quail and lesserknown Poultry; Ladoke Akintola University of Technology, Ogbomoso, Nigeria. pp. 32-47

Aro, S. O., Ajepe, O. A. and Adejumo, D. O. 2011. Prediction of body weight and progression of sexual development from scrotal traits of pigs. In: Adeniji, A. A., Olatunji, E. A., Gana, E. S. (eds). $36^{\text {th }}$ Annual Conference of Nigerian Society for Animal Production (NSAP);
University of Abuja, Nigeria. pp. 238-241

Aro, S. O., Akinmoladun, F. O. and A d e g b e n r o, M . 2014 . Characteristics and hatchability of African Bush Fowl's (Francolinus bicalcaratus) eggs collected from the wild: A prelude to its domestication and adaptive breeding. In: Abdullah, A. R., Tayo, G. O., Okubanjo, A. O., Akinsoyinu, O. A. (eds). 39 Annual Conference of Nigerian Society for Animal Production (NSAP); Babcock University, Ilishan-Remo, Nigeria. pp. 558560

Cetin, M., Sengul, T., Sogut, B. and Yurtseven, S. 2007. Comparison of growth models of male and female partridges. Journal of Biology, 6:964-968

Clark, G. and Clark, K. A. 2015. Bird Tails. Text Copyright, Gary Clark. Photography Copyright, K a t h y Adams Clark. All rights reserved.-

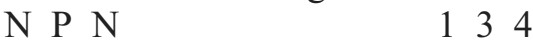
www.kathyadamsclark.com

Crowe, T. M., Bowie, R. C. K., Bloomer, P., Mandiwana, T. G., Hedderson, T. A. J., Randi, E., Pereira, S. L. and Wakeling, J. 2006 . P h y lo g e n e t i c s, biogeography and classification of, and character evolution in, game birds (Aves: Galliformes): effects of character exclusion, data partitioning and missing data. Cladistics, 22:495-532

Goransson, G., Von Schantz, T., Froberg, I., Helgee, A. and Wittzell, $H$. 1990. Male characteristics, visibility and harem size in the pheasant, Phasianus colchicus. Animal Behaviour, 40: 89-104

Hauptmanová, K., Malý, M. and 
Literák, I. 2006. Changes of haematological parameters in common pheasant throughout the year. Veterinary Medicine of Czechoslovakia, 51:29-34

IUCN, 2009. International Union of the Conservation of Nature: World pheasant association and IUCN/SSC re-introduction specialist group (eds.). Guidelines for the re-introduction of Galliformes for conservation purposes. Gland, Switzerland: IUCN and Newcastle-tupon-Tyne, UK: World Pheasant Association. pp. 86

Jain, N. C. 1986. Schalm's Veterinary Hematology. Philadelphia, USA: Lea and Fabiger

Jain, N. C. 1993. Essentials of Veterinary Hematology. Philadelphia, USA: Lea and Fabiger

Johnsgard, P. A. 1988. The Quails, Partridges, and Francolins of the World. Oxford, UK: Oxford University Press

Johnsgard, P. A. 1999. The Pheasants of the World, 2nd Edition. Smithsonian Institution Press

Keçeci, T. and Çöl, R. 2011. Haematological and biochemical values of the blood of pheasants (Phasianus colchicus) of different ages. Turkish Journal of Veterinary and Animal Science, 35: 149-156

Kokoszyński，D., Bernacki，Z., Korytkowska, H., Wilkanowska, A. and Frieske, A. 2013. Carcass composition and meat quality of grey partridge (Perdix perdix L.). Journal of Central European Agriculture, 14: 378-387

Mandiwane-Neudani, T. G. 2014. Taxonomy, phylogeny and biogeography of francolins ('Francolinus'spp.). PhD, Percy
FitzPatrick Institute of African Ornithology, University of Cape Town, South Africa

Najira, S., Gaddoun, A., Ben Hamouda, M., Djemali, M. and Khaldi, G. 2007. Growth model adjustment of local goat population under pastoral condition in Tunisian arid zone. Journal of Agriculture, 6: 6167

Ntiamao-Baidu, Y. 1997. Wildlife and food security in Africa. FAO Conservation Guide 33, Food and Agriculture Organization of the United Nations, Rome, Italy

S.P.S.S. Statistical Package for Social Scientists 2006. S.P.S.S Base 15.0 User's Guide, S.P.S.S. Inc., Chicago, IL.

Schmidt, E. M., Paulillo, A. C., Santin, E., Dittrich, R. L. and Oliveira, E. G. 2007. Hematological and serum chemistry values for the ring$\mathrm{n} \quad \mathrm{e} \quad \mathrm{c} \quad \mathrm{k} \quad \mathrm{e} \quad \mathrm{d}$ pheasant (Phasianus colchicus): Variation with sex and age. International Journal of Poultry Science, 6: 137-139

Straková, E., Suchý, P., Kábelová, R., Vitula, F. and Herzig, I. 2010. Values of selected haematological indicators in six species of feathered games. Acta Veterinaria Brno, 79: S3-S8

Van Niekerk, J. H., Barendse, M. and Mare, F. 2009. Behaviour of redneckedspurfowl(Pternistis afer) in the Boknes and Cannon Rock coastal resorts, Alexandria district, Eastern Cape Province, South Africa. Ostrich, 80: 43-45

Van Niekerk, J. H. 2012. Vocal behaviour of Orange River Francolin (Scleroptila levaillantoides) based on visual and sound playback surveys. Ostrich, 83: 147-152 
Van Niekerk, J. H. 2013. Vocal structure, behaviour and partitioning of all 23

Pternistis spp. into homologous sound (and monophyletic) groups.

Chinese Birds, 4: 210-231. DOI:

$10.5122 /$ cbirds. 2013.0020

Received: $17^{\text {th }}$ April, 2019

Accepted: $25^{\text {th }}$ July, 2019 